\title{
International
}

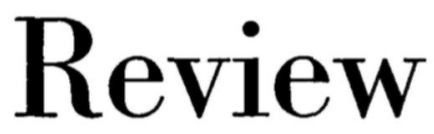

of the
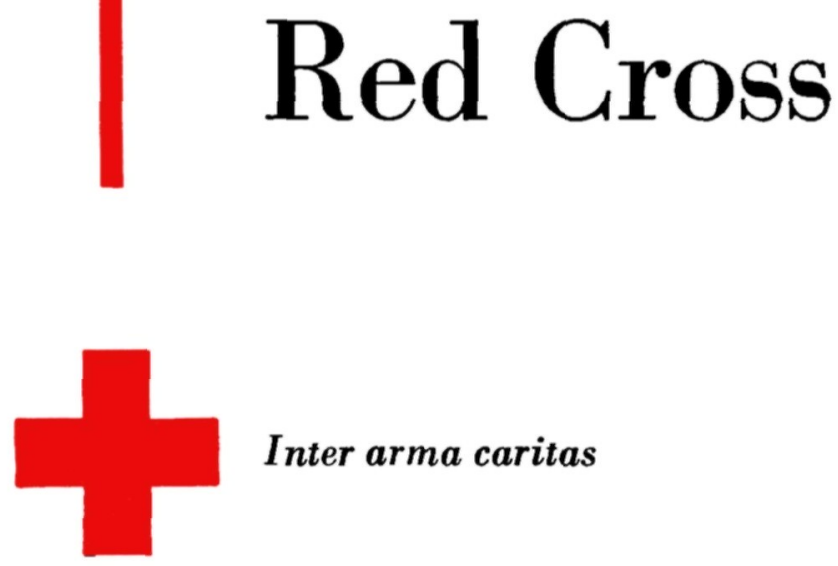

Inter arma caritas

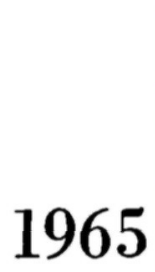

GENEVA

INTERNATIONAL COMMITTEE OF THE RED CROSS FOUNDED IN 1863 


\section{INTERNATIONAL COMMITTEE OF THE RED CROSS}

SAMUEL A. GONARD, former Army Corps Commander, Professor at the Graduate Institute of International Studies, University of Geneva, President (member since 1961)

JACQUES CHENEVIEkRE, Hon. Doctor of Literature, Honorary Vice-President (1919)

MARTIN BODMER, Hon. Doctor of Philosophy, Vice-President (1940)

LEOPOLD BOISSIER, Doctor of Laws, Honorary Professor at the University of Geneva, former Secretary-General to the Inter-Parliamentary Union (1946)

PAUL RUEGGER, former Swiss Minister to Italy and the United Kingdom, Member of the Permanent Court of Arbitration (1948)

RODOLFO OLGIATI, Hon. Doctor of Medicine, former Director of the Don Suisse (1949)

MARGUERITE VAN BERCHEM, former Head of Section, Central Prisoners of War Agency (1951)

FREDERIC SIORDET, Lawyer, Counsellor of the International Committee of the Red Cross from 1943 to 1951 (1951)

GUILLAUME BORDIER, Certificated Engineer E.P.F., M.B.A. Harvard, Banker (1955)

ADOLPHE FRANCESCHETTI, Doctor of Medicine, Professor of clinical ophthalmology at Geneva University (1958)

HANS BACHMANN, Doctor of Laws, Assistant Secretary-General to the International Committee of the Red Cross from 1944 to 1946, Vice-President (1958)

JACQUES FREYMOND, Doctor of Literature, Director of the Graduate Institute of International Studies, Professor at the University of Geneva (1959)

DIETRICH SCHINDLER, Doctor of Laws, Professor at the University of Zurich (1961)

HANS MEULI, Doctor of Medicine, Brigade Colonel, former Director of the Swiss Army Medical Service (1961)

MARJORIE DUVILLARD, Directress of " Le Bon Secours" Nursing School (1961)

MAX PETITPIERRE, Doctor of Laws, former President of the Swiss Confederation (1961)

\section{Honorary members}

Miss LUCIE ODIER, Honorary Vice-President; Messrs. FRÉDERIC BARBEY, CARL J. BURCKHARDT and PAUL CARRY, Miss SUZANNE FERRIERE, Messrs. EDOUARD de HALLER, PAUL LOGOZ, ALFREDO VANNOTTI, ADOLF VISCHER.

Directorate: ROGER GALLOPIN, Doctor of Laws, Executive Director JEAN PICTET, Doctor of Laws, Director for General Affairs CLAUDE PILLOUD, Deputy Director for General Affairs 


\title{
INTERNATIONAL REVIEW \\ OF THE. RED CROSS
}

\author{
FIFTH YEAR - No. 47 \\ FEBRUARY 1965
}

\section{CONTENTS}

F. SIORDET : Dissemination of the Geneva Conventions .

J. DES CILLEULS: Plan of action for the dissemination of the Geneva Conventions

\section{INTERNATIONAL COMMITTEE OF THE RED CROSS}

EXTERNAL ACTIVITIES

Malaysia - Viet Nam - Yemen - Congo - Ceylon - Laos . . .

\section{IN GENEVA}

Resignation . . . . . . . . . . . . . . . . . . . . . . . . . 76

At the University of Geneva $\quad$. . . . . . . . . . . . . . . . . . . . . . . . 79

At the Central Tracing Agency . . . . . . . . . . . . . . . . . . . 80

\section{IN THE RED CROSS WORID}

Dissemination of the Geneva Conventions in the Federal Republic of Germany

\section{MISCELLANEOUS}

International Co-operation 


\section{FRENCH EDITION OF THE REVIEW}

The French edition of this Review is issued every month under the title of Revue internationale de la Croix-Rouge. It is, in principle, identical with the English edition and may be obtained under the same conditions.

\section{SUPPLEMENTS TO THE REVIEW}

$$
\text { * }
$$

SPANISH

F. Siordet: Difusión de los Convenios de Ginebra. - La enseñanza del derecho humanitario. - Los Jóvenes manifestan...

GERMAN

F. Siordet: Verbreitung der Genfer Abkommen. - Demission. Der Unterricht des humanitären Völkerrechts. - Solidaritätsbeweis der Jugend...

\section{THE \\ INTERNATIONAL REVIEW OF THE RED CROSS}

is published each month by the International Committee of the Red Cross

7, Avenue de la Paix, Geneva, Switzerland Postal Cheque No. 12.1767

Annual subscription : Sw. fr. $25 .-(\$ 6)$

Single copies Sw. fr. $2.50(\$ 0.60)$

Editor: J.G. LOSSIER 